\title{
Correspondence
}

\section{Accelerated onset of rocuronium}

To the Editor:

I read with interest the recent paper by Naguib on the use of priming technique for accelerating the onset of action of rocuronium. ${ }^{1}$

Dr. Naguib is obviously a firm believer in the usefulness of the priming technique. Although we have not tested the priming principle for rocuronium we have not been able to observe any effect on the onset or duration of action of atracurium and vecuronium. ${ }^{2}$ Although Dr. Naguib has correctly quoted an onset time of $88.9 \mathrm{sec}$ reported by us using a $0.6 \mathrm{mg} \cdot \mathrm{kg}^{-1}$ dose of rocuronium, ${ }^{3}$ this was obtained using a single twitch mode of stimulation at $0.1 \mathrm{~Hz}$ compared with the train-of-four (TOF) mode of stimulation used by Dr. Naguib in his study. Using a train-of-four mode of monitoring we were able to attain complete block with a $0.6 \mathrm{mg} \cdot \mathrm{kg}^{-1}$ dose of rocuronium in approximately $60 \mathrm{sec}^{4}$ There are other studies which have shown that using a TOF mode of stimulation results in a faster onset than by using a single twitch mode of stimulation at $0.1 \mathrm{~Hz}$. Dr. Naguib has also suggested that the difference in his results and those of Foldes $e t$ al. ${ }^{5}$ could be due to the use of the different priming doses in the two studies. It is difficult to understand how a priming dose of $0.1 \mathrm{mg} \cdot \mathrm{kg}^{-1}$ would not produce any acceleration in the onset of rocuronium but a dose of $0.06 \mathrm{mg} \cdot \mathrm{kg}^{-1}$ would. It is likely that priming would contribute little to the onset of effect of a rapidacting drug like rocuronium. There is no evidence from Dr. Naguib's study that a three minute interval for priming is more appropriate than a four minute interval.

It is not logical to look at intubating conditions in the various groups when patients are administered a dose of thiopentone immediately before intubation. Dr. Naguib's study has in any case shown no improvement in the intubating conditions by priming. The study of Cooper et al. where no drugs were administered in the five-minute period before intubation showed that intubating conditions with rocuronium were excellent to good at 60-90 seconds and comparable to those of suxamethonium even without any priming.

R.K. Mirakhur MD Phd FRCA FFARCSI

Department of Anaesthetics

The Queen's University of Belfast

\author{
Whitla Medical Building \\ 97 Lisburn Road \\ Belfast BT12 6BA \\ $\mathrm{N}$ Ireland (UK)
}

\section{REFERENCES}

1 Naguib $M$. Different priming techniques, including mivacurium, accelerate the onset of rocuronium. Can J Anaesth 1994; 41: 902-7.

2 Brady MM, Mirakhur RK, Clarke RSJ. Administration of vecuronium, atracurium and pancuronium in divided doses: effect on onset and duration of action. Eur $\mathbf{J}$ Anaesth 1988; 5: 243-9.

3 Cooper AR, Mirakhur RK, Clarke RSJ, Boules Z. Comparison of intubating conditions after administration of ORG 9426 (rocuronium) and suxamethonium. $\mathrm{Br} \mathrm{J}$ Anaesth 1992; 69: 269-73.

4 Cooper $R$, Mirakhur RK, Maddineni VR. Neuromuscular effects of rocuronium (Org 9426) during fentanyl and halothane anaesthesia. Anaesthesia 1993; 48: 103-5.

5 Foldes FF, Nagashima H, Nguyen HD, Schiller WS, Mason MM, Ohta $Y$. The neuromuscular effects of ORG 9426 in patients receiving balanced anesthesia. Anesthesiology 1991; 75: 191-6.

\section{REPLY}

Thank you for the opportunity to comment on the letter of Dr. Mirakhur. I was surprised to know that Dr. Mirakhur is still questioning the efficacy of the priming principle. The literature on priming is very comprehensive and a Medline search revealed 96 citations about the priming principle. Failure of Dr. Mirakhur and his colleagues to observe any acceleration of the onset of atracurium and vecuronium with priming does not mean that we should bury this technique. The precise doses used for priming and the time interval separating them are obviously of crucial importance ${ }^{2-4}$ (see Jones for review). In contrast to $\mathrm{Dr}$. Mirakhur's opinion, different investigators have reported that priming accelerated the onset of neuromuscular blockade induced by atracurium and vecuronium. ${ }^{2-4,6-8}$ Although Dr. Mirakhur reported previously that the duration of clinical relaxation of vecuronium was significantly prolonged by giving it in divided (priming) doses, ${ }^{9}$ we agree with the statement in his letter that priming does not affect the duration of action of atracurium and vecuronium. Considering the above comments and taking into account that rocuronium has a rapid onset of action, it is most likely that the difference in our results ${ }^{10}$ and those of Foldes et al. difference in the size of the priming dose and priming interval. We have also pointed out in the discussion 10 that Foldes et al.," by changing the size of the priming dose and priming interval, noted that priming accelerated the onset of rocuronium in the rat. 
Our consistent observation with the priming technique indicates that acceleration of onset of nondepolarizing neuromuscular blocking agents does not improve intubating conditions. We never claimed that priming per se improved intubating conditions. ${ }^{2,3,10,13}$ This misconception should be corrected. This is, however, to be contrasted with Dr. Mirakhur's observation that priming improved intubating conditions. ${ }^{9}$ We noted earlier that administration of $2 \mathrm{mg} \cdot \mathrm{kg}^{-1}$ thiopentone before tracheal intubation resulted in improvement of intubating conditions. ${ }^{13}$ Therefore, it is logical to administer a dose of thiopentone approximately $30 \mathrm{sec}$ before intubation. The factors contributing to the adequacy of intubation conditions have been discussed elsewhere. ${ }^{3}$ Without prior administration of thiopentone, intubating conditions would have been less than perfect and still it would have been similar among the groups. ${ }^{\text {If }}$

The onset of complete neuromuscular block (onset time) following rocuronium $0.6 \mathrm{mg} \cdot \mathrm{kg}^{-1}$ observed in our study was 90 (71-109) sec (mean and 95\% confidence interval). ${ }^{10}$ Using train-of-four (TOF) stimulation, Magorian, Flannery and Miller ${ }^{75}$ reported that the onset time of rocuronium 0.6 $\mathrm{mg} \cdot \mathrm{kg}^{-1}$ was $89 \pm 33 \mathrm{sec}$ (mean $\pm S D$ ) and afier doubling the dose of rocuronium to $1.2 \mathrm{mg} \cdot \mathrm{kg}^{-1}$, the onset time decreased to $55 \pm 14 \mathrm{sec}^{15}$ Similarly, Foldes et al. " and Mayer et al. ${ }^{16}$ using TOF stimulation reported that the onset time of rocuronium $0.6 \mathrm{mg} \cdot \mathrm{kg}^{-1}$ was $1.49 \pm 0.12 \mathrm{~min}(89.4 \mathrm{sec})$ and $1.8 \pm 0.4 \min (108 \mathrm{sec})$, respectively. None of the aforementioned investigators have been able to attain the 60-sec onset reported by Dr. Mirakhur. ${ }^{14}$ Consistent with our data, Magorian et al. ${ }^{15}$ also found that intubating conditions were similar after rocuronium and succinylcholine. In addition, they noted that intubating conditions did not differ after rocuronium or vecuronium. ${ }^{\text {Is }}$

Mohamed Naguib MB BCh MSc FFARCSI MD

Department of Anaesthesia and ICU

Faculty of Medicine at King Khalid University Hospital

PO Box 7805

Riyadh 11472

\section{REFERENCES}

1 Brady MM, Mirakhur RK, Clarke RSJ. Administration of vecuronium, atracurium and pancuronium in divided doses: effect on onset and duration of action. Eur $\mathrm{J}$ Anaesth 1988; 5: 243-9.

2 Naguib $M$, Gyasi $H K$, Abdulatif $M$, Absood $G H$. Rapid tracheal intubation with atracurium - a comparison of priming intervals. Can Anaesth Soc J 1986; 33: 150-6.

3 Naguib $M$, Abdulatif $M$, Absood GH. The optimal priming dose for atracurium. Can Anaesth Soc J 1986; 33: 453-7.

4 Taboada JA, Rupp SM, Miller RD. Refining the priming principle for vecuronium during rapid-sequence induction of anesthesia. Anesthesiology 1986; 64: 243-7.

5 Jones $R M$ The priming principle: how does it work and should we be using it? Br J Anaesth 1989; 63: 1-3.

6 Schwarz S, lias W, Lackner F, Mayrhofer O, Foldes FF. Rapid tracheal intubation with vecuronium: the priming principle. Anesthesiology 1985; 62: 388-91.

7 Kunjappan VK, Brown EM, Alexander GD. Rapid sequence induction using vecuronium. Anesth Analg 1986; 65: 503-6.

8 Baumgarten $R K$, Carter CE, Reynolds WJ, Brown Do JL, DeVera $H V$. Priming with nondepolarizing relaxants for rapid tracheal intubation: a double-blind evaluation. Can J Anaesth 1988; 35: 5-11.

9 Mirakhur RK, Lavery GG, Gibson FM, Clarke RSJ. Intubating conditions after vecuronium and atracurium given in divided doses (the priming technique). Acta Anaesthesiol Scand 1986; 30: 347-50.

10 Naguib $M$. Different priming techniques, including mivacurium, accelerate the onset of rocuronium. Can J Anaesth 1994; 41: 902-7.

11 Foldes $F F$, Nagashima $H$, Nguyen $H D$, Schiller WS, Mason MM, Ohta $Y$. The neuromuscular effects of ORG9426 in patients receiving balanced anesthesia. Anesthesiology 1991; 75: 191-6.

12 Foldes FF, Nagashima H, Kornak PH. Effect of priming. Anaesthetic Pharmacology Review 1993; 1: 49-56.

13 Naguib $M$, Abdulatif $M$, Gyasi $H K$, Absood $G H$. Priming with atracurium: improving intubating conditions with additional doses of thiopental. Anesth Analg 1986; 65: 1295-9.

14 Cooper R, Mirakhur RK, Maddineni VR. Neuromuscular effects of rocuronium (Org 9426) during fentanyl and halothane anaesthesia. Anaesthesia 1993; 48: 103-5.

15 Magorian T, Flannery KB, Miller RD. Comparison of rocuronium, succinylcholine, and vecuronium for rapidsequence induction of anesthesia in adult patients. Anesthesiology 1993; 79: 913-8.

16 Mayer $M$, Doenicke $A$, Hofmann $A$, Peter $K$. Onset and recovery of rocuronium (ORG 9426) and vecuronium under enflurane anaesthesia. Br J Anaesth 1992; 69: 511-2.

\section{An unusual explanation for a failed spinal}

To the Editor:

We recently encountered a surprising and novel equipment defect that, had it not been noticed, would have led to a failed spinal block.

A 41-yr-old man in good health presented for a haemorrhoidectomy. After placement of an $\dot{N}$ cannula and administration midazolam $2 \mathrm{mg} \dot{\omega}$ the patient was asked to sit up and a spinal needle was introduced at the $\mathrm{L}_{3}-\mathrm{L}_{4}$ interspace without the aid of an introducer needle. Moderate difficulty was encountered in the placement of the needle and several attempts were made with a 25-gauge Quinke point needle ("Phoenix" spinal needle, Kobayashi Shoji K.K., Tokyo, Japan). With proper positioning of the spinal needle free flow of CSF was noted. A syringe containing hyperbaric bupivicaine $5 \mathrm{mg}$ was attached to the needle. Upon injecting, however, it was noted that a jet of fluid was spraying from the proximal portion of the needle shaft, $2 \mathrm{~cm}$ from the proximal end of the $9 \mathrm{~cm}$ needle. An additional $7.5 \mathrm{mg}$ of hyperbaric bupivacaine was injected in the hope that at least some of the anaesthetic would exit the distal end of the needle. The patient was then immediately returned to the supine position. Examination of the patient revealed that a sen- 